\title{
Evaluating acute inflammation's effects on hepatic triglyceride content in experimentally induced hyperlipidemic dairy cows in late lactation
}

\author{
E. A. Horst, ${ }^{1}$ L. M. van den Brink, ${ }^{1} \odot$ E. J. Mayorga, ${ }^{1} \odot$ M. Al-Qaisi, ${ }^{1} \odot$ S. Rodriguez-Jimenez, ${ }^{1}$ B. M. Goetz, ${ }^{1}$ \\ M. A. Abeyta, ${ }^{1}$ S. K. Kvidera, ${ }^{1}$ L. S. Caixeta, ${ }^{2}$ (D) R. P. Rhoads, ${ }^{3}$ (D) and L. H. Baumgard ${ }^{1 *}($ (D) \\ ${ }^{1}$ Department of Animal Science, lowa State University, Ames 50011 \\ ${ }^{2}$ Department of Veterinary Population Medicine, University of Minnesota, St. Paul 55108 \\ ${ }^{3}$ Department of Animal and Poultry Sciences, Virginia Tech University, Blacksburg 24061
}

\section{ABSTRACT}

Inflammation appears to be a predisposing factor and key component of hepatic steatosis in a variety of species. Objectives were to evaluate effects of inflammation [induced via intravenous lipopolysaccharide (LPS) infusion] on metabolism and liver lipid content in experimentally induced hyperlipidemic lactating cows. Cows $(765 \pm 32 \mathrm{~kg}$ of body weight; $273 \pm 35 \mathrm{~d}$ in milk) were enrolled in 2 experimental periods $(\mathrm{P})$; during P1 (5 d), baseline data were obtained. At the start of P2 (2 d), cows were assigned to 1 of 2 treatments: (1) intralipid plus control (IL-CON; $3 \mathrm{~mL}$ of saline; $\mathrm{n}=5$ ) or (2) intralipid plus LPS (IL-LPS; $0.375 \mu \mathrm{g}$ of LPS/kg of body weight; $\mathrm{n}=5$ ). Directly following intravenous bolus (saline or LPS) administration, intralipid (20\% fat emulsion) was intravenously infused continuously $(200 \mathrm{~mL} / \mathrm{h})$ for $16 \mathrm{~h}$ to induce hyperlipidemia during which feed was removed. Blood samples were collected at $-0.5,0,4,8,12,16,24$, and $48 \mathrm{~h}$ relative to bolus administration, and liver biopsies were obtained on $\mathrm{d} 1$ of $\mathrm{P} 1$ and at 16 and $48 \mathrm{~h}$ after the bolus. By experimental design (feed was removed during the first $16 \mathrm{~h}$ of $\mathrm{d}$ 1 ), dry matter intake decreased in both treatments on d 1 of P2, but the magnitude of reduction was greater in LPS cows. Dry matter intake of IL-LPS remained decreased on d 2 of P2, whereas IL-CON cows returned to baseline. Milk yield decreased in both treatments during P2, but the extent and duration was longer in LPS-infused cows. Administering LPS increased circulating LPS-binding protein (2-fold) at $8 \mathrm{~h}$ after bolus, after which it markedly decreased $(84 \%)$ below baseline for the remainder of P2. Serum amyloid A concentrations progressively increased throughout P2 in IL-LPS cows (3-fold, relative to controls). Lipid infusion gradually increased nonesterified fatty acids and triglycerides

Received April 9, 2020.

Accepted May 29, 2020.

*Corresponding author: baumgard@iastate.edu in both treatments relative to baseline (3- and 2.5-fold, respectively). Interestingly, LPS infusion blunted the peak in nonesterified fatty acids, such that concentrations peaked (43\%) higher in IL-CON compared with IL-LPS cows and heightened the increase in serum triglycerides (1.5-fold greater relative to controls). Liver fat content remained similar in IL-LPS relative to P1 at $16 \mathrm{~h}$; however, hyperlipidemia alone (IL-CON) increased liver fat $(36 \%$ relative to $\mathrm{P} 1)$. No treatment differences in liver fat were observed at $48 \mathrm{~h}$. In IL-LPS cows, circulating insulin increased markedly at $4 \mathrm{~h}$ after bolus (2-fold relative to IL-CON), and then gradually decreased during the $16 \mathrm{~h}$ of lipid infusion. Inducing inflammation with simultaneous hyperlipidemia altered the characteristic patterns of insulin and LPS-binding protein but did not cause fatty liver.

Key words: lipopolysaccharide, nonesterified fatty acids, fatty liver

\section{INTRODUCTION}

Early-lactation cows are typically unable to consume enough energy to meet the requirements of both maintenance and milk production. As a result, cows enter into a state of negative energy balance and marked alterations in whole-body carbohydrate and lipid metabolism are employed to spare glucose for milk synthesis. In particular, hypoinsulinemia and reduced skeletal muscle and adipose tissue insulin sensitivity are key components of this homeorhetic adaptation (Bauman and Currie, 1980). Although these normal strategies are crucial for ensuring a successful lactation initiation, metabolic maladaptation and subsequent hepatic steatosis and subclinical ketosis occur in a large percentage of cows (Drackley, 1999; Bobe et al., 2004). Ketosis is traditionally thought to result from excessive adipose tissue mobilization (Baird, 1982; Drackley, 1999). The liver takes up nonesterified fatty acids (NEFA) in proportion to blood concentrations (Herdt, 1988), kinetics which presumably causes fatty liver and excessive ketone body synthesis (Grummer, 1993). 
In nonruminants, hepatic steatosis is commonly observed during intestinal hyperpermeability pathologies (Ilan, 2012; Hamarneh et al., 2017). Hepatocyte and Kupffer cell recognition of gut-derived LPS triggers inflammatory cytokine production, which negatively affects hepatic lipid trafficking (Lanza-Jacoby and Tabares, 1990; Endo et al., 2007; Stienstra et al., 2010). In laboratory models, inflammation's role on hepatic lipid metabolism is confirmed by LPS and cytokine recognition interference experiments that ameliorate liver fat accumulation (Endo et al., 2007; Jin et al., 2017; Jia et al., 2018). In nonruminants it is generally believed that increased hepatic NEFA delivery and inflammation must coincide for fatty liver disease progression, a concept known as the 2-hit hypothesis (Day and James, 1998; Csak et al., 2011). Regardless, it appears that hepatic steatosis is more complex than historically assumed.

A systemic inflammatory response is observed in most periparturient dairy cows (Humblet et al., 2006), even in seemingly healthy ones (Bionaz et al., 2007; Bertoni et al., 2008; Graugnard et al., 2012). The magnitude and persistence of inflammation appears dependent on the frequency and severity of immune insults (Bertoni et al., 2008; Trevisi and Minuti, 2018) and is predictive of fatty liver (Ohtsuka et al., 2001; Ametaj et al., $2005,2010)$. In agreement with the rodent literature, administering tumor necrosis factor- $\alpha$ (TNF- $\alpha$; an inflammatory cytokine) in late-lactation cows increased liver triglyceride (TG) content (Bradford et al., 2009). In contrast, we were unable to recreate hepatic steatosis in mid-lactation cows administered LPS to induce systemic inflammation (Horst et al., 2019b). A possible explanation for the absence of hepatic steatosis in our aforesaid inflammation model may have been the lack of an endogenous increase in NEFA comparable to transition cows. The early-lactation cow would be the ideal experimental model of periparturient inflammation because they are naturally hyperlipidemic. However, a host of other physiological events occurring during early lactation (including endocrine, metabolic, and inflammatory events) are highly variable, resulting in sequelae that hinder our capacity to intensely investigate the effect of a periparturient systemic inflammation on lipid liver accumulation. For this reason, we chose to use a model of mid-lactation cows whose production and metabolic parameters are in a relative "steady-state" combined with continuous infusion of intralipid (IL) to sustain increased NEFA concentrations as described previously (Chelikani et al., 2003; Caixeta et a., 2017; Lamp et al., 2018). Therefore, our objective was to evaluate the effects of inflammation on metabolism and liver lipid by simultaneously recreating hyperlipidemia and inflammation in cows during estab- lished lactation. We hypothesized that acute systemic inflammation and hyperlipidemia would exacerbate liver lipid accumulation similarly to that observed in poorly transitioning dairy cows.

\section{MATERIALS AND METHODS}

\section{Animals and Experimental Design}

All procedures were approved by the Iowa State University Institutional Animal Care and Use Committee. Ten nonpregnant lactating Holstein cows (765 $\pm 32 \mathrm{~kg} \mathrm{BW} ; 273 \pm 35 \mathrm{DIM}$; parity $3 \pm 0.4$ ) were housed in individual box-stalls $(4.57 \times 4.57 \mathrm{~m})$ at the Iowa State University Dairy Farm (Ames) in August 2018. Cows were allowed $3 \mathrm{~d}$ to acclimate, during which they were implanted with bilateral jugular catheters. In brief, cows were restrained in a head gate, the neck was cleaned with alternating povidone-iodine scrub and $70 \%$ ethanol 3 times. The jugular vein was occluded, and the vein was localized with a 14 -gauge, $3.75-\mathrm{cm}$ introducer (MILA International, Erlanger, KY) using a percutaneous technique. Once in the vein, sterilized Tygon tubing (Saint-Gobain Performance Plastics, Akron, $\mathrm{OH})$ was passed through the introducer, the introducer was removed and the tubing was sutured to the skin using a tape butterfly. A tubing adapter was fitted to the external end of the tubing, which was flushed with $5 \mathrm{~mL}$ of heparinized saline. Cows were fed ad libitum once daily $(0600 \mathrm{~h})$ with a diet formulated to meet or exceed the predicted requirements (NRC, 2001) of energy, protein, minerals, and vitamins (Table 1). Cows were milked twice daily (0600 and $1800 \mathrm{~h}$ ) throughout the experiment, and yield was recorded. A sample for composition analysis was obtained at each milking and stored at $4^{\circ} \mathrm{C}$ with a preservative (bronopol tablet; D \& F Control System, San Ramon, CA) until analysis by Dairy Lab Services (Dubuque, IA) using AOAC International-approved infrared analysis equipment and procedures (AOAC International, 1995). Rectal temperature was recorded after each milking using a digital thermometer (GLA M700 Digital Thermometer, San Luis Obispo, CA).

The trial consisted of 2 experimental periods; period 1 (P1) lasted $5 \mathrm{~d}$ and served as the baseline (data generated for covariate analysis). During period 2 (P2), which lasted $2 \mathrm{~d}$, animals were randomly assigned to 1 of 2 intravenous treatments: (1) IL infusion plus control (IL-CON; IL infusion and $3 \mathrm{~mL}$ of sterile saline; $\mathrm{n}=$ 5) or 2) IL infusion plus LPS (IL-LPS; IL infusion and $0.375 \mu \mathrm{g}$ of LPS $/ \mathrm{kg}$ of BW; $\mathrm{n}=5)$. Lipopolysaccharide (Escherichia coli O55:B5; Sigma-Aldrich, St. Louis, MO) was dissolved in sterile saline at a concentration of $65.1 \mu \mathrm{g} / \mathrm{mL}$ and passed through a $0.2-\mu \mathrm{m}$ sterile syringe 
filter (Thermo Scientific; Waltham, MA). The total volume of LPS solution administered was approximately 4 $\mathrm{mL}$. Each respective treatment bolus was administered following the morning milking and 0 min blood sample collection. Immediately (within $30 \mathrm{~s}$ ) following bolus (saline or LPS) administration, cows in both treatments were continuously intravenously infused with $20 \%$ IL solution (Fresenius Kabi, Deerfield, IL; consisting primarily of $\mathrm{C} 18: 2, \mathrm{C} 18: 1, \mathrm{C} 16: 0, \mathrm{C} 18: 3, \mathrm{C} 18: 0)$ at a rate of $200 \mathrm{~mL} / \mathrm{h}$ for $16 \mathrm{~h}$ using calibrated infusion pumps (Deltec 3000, Deltec Inc., St. Paul, MN) as previously described (Caixeta et al., 2017). Cows were tethered during the 16 -h infusion period (but allowed to stand up and lay down) to allow for frequent sampling and constant connection with the infusion pump. Water was provided ad libitum and feed was removed from all cows $\sim 0.5 \mathrm{~h}$ before bolus administration. Animals remained fasted during the 16 -h data collection period to eliminate the confounding effect of dissimilar nutrient intake.

Rectal temperature was obtained at -0.5 and $0 \mathrm{~h}$ relative to LPS administration, every $0.5 \mathrm{~h}$ for the first $8 \mathrm{~h}$, and every $4 \mathrm{~h}$ for the next $8 \mathrm{~h}$. Plasma and serum samples were collected daily following the morning milking during $\mathrm{P} 1$ and at $-0.5,0,4,8,12,16,24$, and $48 \mathrm{~h}$ relative to bolus administration (and the start of IL infusion) during P2. Serum samples were allowed to clot at room temperature for $1 \mathrm{~h}$ before centrifugation. Plasma and serum were harvested following cen-

Table 1. Ingredients and composition of $\operatorname{diet}^{1}$

\begin{tabular}{lc}
\hline Item & Value $^{2}$ \\
\hline Ingredient (\% of DM) & \\
Corn silage & 30.1 \\
Alfalfa hay & 3.4 \\
Baleage & 19.9 \\
Ground corn & 18.9 \\
Corn gluten feed & 10.4 \\
SoyPlus & 4.3 \\
Soybean meal & 1.7 \\
Whole cottonseed & 3.5 \\
Molasses & 0.9 \\
Mineral and protein mix & 6.9 \\
Chemical analysis (\% of DM) & \\
Starch & 21.1 \\
CP & 15.8 \\
NDF & 37.1 \\
ADF & 26.6 \\
NE & 1.54 \\
\hline
\end{tabular}

${ }^{1}$ Values represent an average of ration nutrient summary reports collected throughout the trial. Diet moisture averaged 57.0\%.

${ }^{2}$ Average nutrient levels: $4.78 \%$ fat, $0.80 \% \mathrm{Ca}, 0.45 \% \mathrm{P}, 0.35 \% \mathrm{Mg}$, $0.21 \% \mathrm{~S}, 1.26 \% \mathrm{~K}, 0.44 \% \mathrm{Na}, 0.51 \% \mathrm{Cl}, 77.12 \mathrm{mg} / \mathrm{kg} \mathrm{Zn}, 43.86 \mathrm{mg} / \mathrm{kg}$ $\mathrm{Mn}, 3.47 \mathrm{mg} / \mathrm{kg} \mathrm{Fe}, 13.37 \mathrm{mg} / \mathrm{kg} \mathrm{Cu}, 0.75 \mathrm{mg} / \mathrm{kg} \mathrm{Co}, 0.32 \mathrm{mg} / \mathrm{kg} \mathrm{Se}$, $0.75 \mathrm{mg} / \mathrm{kg} \mathrm{I}, 6,052.8 \mathrm{IU} / \mathrm{kg}$ vitamin A, 1,210.6 IU $/ \mathrm{kg}$ vitamin $\mathrm{D}$, and $24.2 \mathrm{IU} / \mathrm{kg}$ vitamin $\mathrm{E}$.

${ }^{3}$ SoyPlus is mechanically processed soybean meal (Dairy Nutrition Plus, Ralston, IA). trifugation at $1,500 \times g$ for $15 \mathrm{~min}$ at $4^{\circ} \mathrm{C}$ and were subsequently frozen at $-20^{\circ} \mathrm{C}$ until analysis. Samples for complete blood count analysis were collected on d 1 and 3 of $\mathrm{P} 1$ and at $4,8,12,16,24,32$, and $48 \mathrm{~h}$ after LPS administration. A 3-mL plasma sample was obtained from the catheter and stored at $4^{\circ} \mathrm{C}$ for approximately $12 \mathrm{~h}$ before submission to the Iowa State University's Department of Veterinary Pathology for analysis. Samples for evaluating blood ionized calcium were measured using an iSTAT handheld machine and cartridge (CG8+; Abbott Point of Care, Princeton, NJ) and were obtained on d 5 of P1 and at 12, 24, and $48 \mathrm{~h}$ after LPS administration.

\section{Tissue Collection and Liver TG Content Analysis}

Liver biopsies were collected from all animals on $\mathrm{d}$ 1 of $\mathrm{P} 1$ following the morning milking and at 16 and $48 \mathrm{~h}$ relative to LPS administration (following blood sampling) during P2 as previously described (Rhoads et al., 2010). Briefly, biopsy sites were shaven, scrubbed with povidone-iodine, and sprayed with $70 \%$ alcohol. The area was locally anesthetized using $2 \%$ lidocaine (MWI Veterinary Supply Co., Glendale, AZ) before performing a percutaneous biopsy with a trocar. All tissue samples were snap frozen in liquid nitrogen and stored at $-80^{\circ} \mathrm{C}$ until analysis. Hepatic TG content was measured as previously described (Morey et al., 2011). Briefly, approximately $20 \mathrm{mg}$ of each liver sample was homogenized with $500 \mu \mathrm{L}$ of chilled PBS. The homogenate was then centrifuged at $8,000 \times g$ for 2 min at $4^{\circ} \mathrm{C}$. Free glycerol was immediately determined using $10 \mu \mathrm{L}$ of supernatant via enzymatic glycerol phosphate oxidase method (Sigma-Aldrich). An additional 300 $\mu \mathrm{L}$ of supernatant was removed and incubated with 75 $\mu \mathrm{L}$ of lipase (MP Biomedicals, Solon, $\mathrm{OH}$ ) at $37^{\circ} \mathrm{C}$ for $16 \mathrm{~h}$ before determining total glycerol using the same method. Free glycerol (before lipase digestion) was subtracted from total glycerol (after lipase digestion) to determine TG content, and this was expressed as a percentage of wet weight of the original sample. The intra-assay coefficients of variation for free glycerol and total glycerol were 6.1 and $2.5 \%$, respectively.

\section{Measurement of Serum and Plasma Parameters}

Serum cortisol and TG, plasma insulin, glucagon, NEFA, BHB, LPS-binding protein (LBP), serum amyloid A (SAA), BUN, and glucose concentrations were determined using commercially available kits according to manufacturers' instructions (cortisol, Enzo Life Sciences Inc., Farmingdale, NY; TG, Sigma-Aldrich; insulin, Mercodia AB, Uppsala, Sweden; glucagon, RD Systems Inc., Minneapolis, MN; NEFA, Wako Chemi- 
cals USA, Richmond, VA; BHB, Pointe Scientific Inc., Canton, MI; LBP, Hycult Biotech, Uden, the Netherlands; SAA, Tridelta Development Ltd., Kildare, Ireland; BUN, Teco Diagnostics Anaheim, CA; glucose, Wako Chemicals USA). All assays were analyzed in duplicates, and a pooled sample was used on each plate to assess inter-assay variation. The inter- and intraassay coefficients of variation for glucose, NEFA, BHB, BUN, insulin, glucagon, LBP, SAA, and cortisol were 6.7 and $4.4 \%, 1.2$ and $3.5 \%, 1.4$ and $8.2 \%, 4.3$ and $4.6 \%, 7.9$ and $6.1 \%, 34.0$ and $13.2 \%, 0.2$ and $8.2 \%$, 4.9 and $8.2 \%$, and 16.7 and $11.4 \%$ respectively. The inter- and intra-assay coefficient of variations for serum free and total glycerol were 13.2 and $11.7 \%$ and 5.9 and $12.5 \%$, respectively.

\section{Statistical Analysis}

The sample size calculation was determined using PROC POWER and was based on the effect of inflammation on liver TG content using $90 \%$ power and a $99 \%$ confidence level. The sample size of 5 cows/ group was based on a detection difference of $1.2 \pm 0.33 \%$ (mean $\pm \mathrm{SD}$ ) in liver TG. Each animal's respective parameter was analyzed using repeated measures with an autoregressive covariance structure (equally spaced time points) for DMI, milk yield, and composition, and a spatial power law covariance structure (unequal spacing) for blood metabolites, inflammatory biomarkers, complete blood count, ionized calcium, and rectal temperature data. The repeated effect was time (h or d) relative to LPS administration. Each specific variable's pre-bolus values (i.e., P1 average or $0 \mathrm{~h}$ time point) served as a covariate for analysis of P2. Effects of treatment, time (h or d relative to bolus administration), and treatment $x$ time interactions were assessed as a completely randomized design using PROC MIXED (SAS Institute, Cary, NC). To evaluate effects of IL infusion, a separate analysis was used to make statistical comparisons with baseline in which the average P1 value (DMI, milk yield, rectal temperature, liver TG content) or $0 \mathrm{~h}$ (blood variables) was included as an additional time point. Data are reported as least squares means and considered significant if $P \leq 0.05$ and a tendency if $0.05<P \leq 0.10$.

\section{RESULTS}

There were no treatment differences in evaluated metrics (other than LBP and milk yield) during P1. Administering LPS induced mild pyrexia $\left(0.8^{\circ} \mathrm{C}\right.$ relative to IL-CON cows) for $\sim 5.5 \mathrm{~h}$ after the bolus ( $P$ $=0.01$; Figure 1A). By experimental design (i.e., feed intake was removed for $16 \mathrm{~h}$ after LPS administration),
DMI decreased in both treatments on d 1 of P2 relative to P1 (34 and $80 \%$ in IL-CON and IL-LPS cows, respectively; $P<0.01)$. However, the degree of DMI reduction on d 1 of P2 was greater (68\%) with LPS infusion relative to control cows $(P<0.01$; Figure $1 \mathrm{~B})$. Dry matter intake from IL-LPS remained decreased on d 2 of P2 (25\% from baseline; $P=0.01)$, whereas in IL-CON cows, it returned to baseline.

During P2, milk yield from IL-LPS cows decreased relative to baseline and control cows (74 and 64\%, respectively, $P<0.01$; Figure $1 \mathrm{C}$ ). Milk yield from ILCON cows decreased on d $1(11 \%$ relative to $\mathrm{P} 1 ; P$ $<0.01)$, but did not differ from baseline on d $2(P>$ $0.30)$. Administering LPS decreased milk lactose (15\%; $P=0.02)$ and increased milk fat and protein percentages (68 and $35 \%$, respectively; $P \leq 0.01$ ) relative to control cows (Table 2). Hyperlipidemia alone did not alter these milk composition variables. Overall MUN was increased in IL-LPS relative to IL-CON cows $(P$ $=0.04$; Table 2). Somatic cell count did not differ by treatment during P2 $(P>0.39$; Table 2).

Administering LPS increased circulating LBP 2-fold at $8 \mathrm{~h}$ postbolus relative to controls, after which it markedly decreased below baseline (84\%; $P<0.01$; Figure 2A). Overall, SAA concentrations increased (3-fold) in LPS-administered cows relative to controls throughout P2 $(P<0.01$; Figure 2B). Circulating LBP and SAA increased in IL-CON at $48 \mathrm{~h}$ relative to P1 $(P \leq 0.02)$. Cortisol levels from LPS-administered cows markedly increased (8-fold) for the first $8 \mathrm{~h}$ after the bolus, whereas in IL-CON cows, it was unchanged $(P$ $<0.01$; Figure 2C). Relative to controls, circulating white blood cells (WBC) from IL-LPS cows decreased $(62 \%)$ for $12 \mathrm{~h}$ after the bolus and then gradually increased $(32 \%)$ throughout P2 $(P<0.01$; Figure 2D). Circulating neutrophils (which make up the majority of WBC) mirrored the WBC pattern following LPS administration $(P<0.01$; Table 3$)$. Relative to IL-CON cows, patterns of circulating lymphocytes, monocytes, and basophils reflected each other with initial leukopenia $(84,102,94 \%$, respectively) followed by a gradual return to baseline post-LPS administration $(P<0.01$; Table 3). Administering LPS decreased circulating platelets $(68 \%)$ relative to controls throughout P2 $(P<$ 0.01; Table 3). Hyperlipidemia alone did not influence circulating leukocyte patterns $(P>0.10)$.

Nonesterified fatty acid concentrations gradually increased in both treatments during the first $12 \mathrm{~h}$ of IL infusion (3-fold, relative to baseline; $P \leq 0.04$ ); however, infusing LPS blunted the NEFA increase at 16 $\mathrm{h}(P=0.01$; Figure $3 \mathrm{~A})$. After cessation of lipid infusion, NEFA concentrations from LPS cows remained increased at $24 \mathrm{~h}$ after bolus (2-fold relative to baseline; $P=0.01$ ), whereas NEFA returned to baseline in IL- 


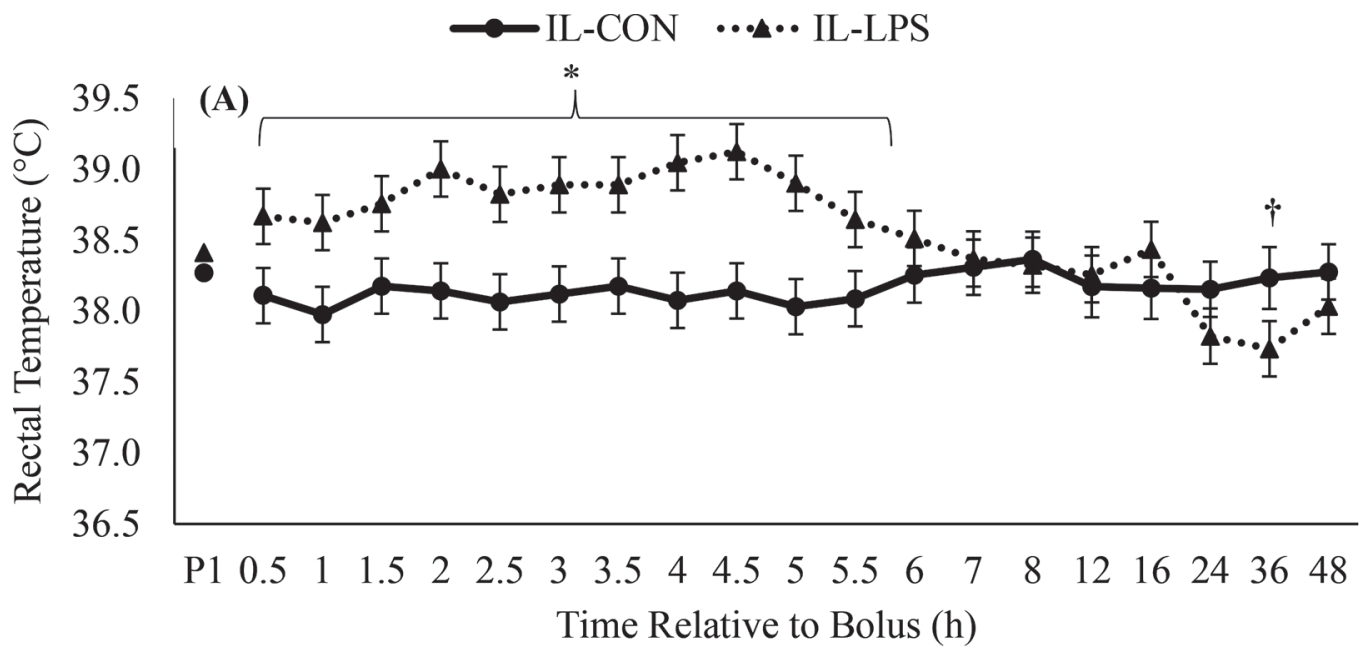

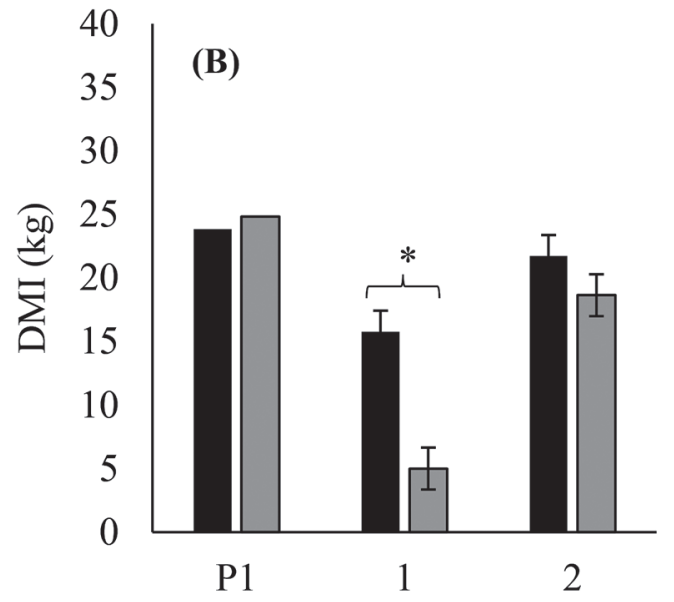

Time Relative to Bolus (d)

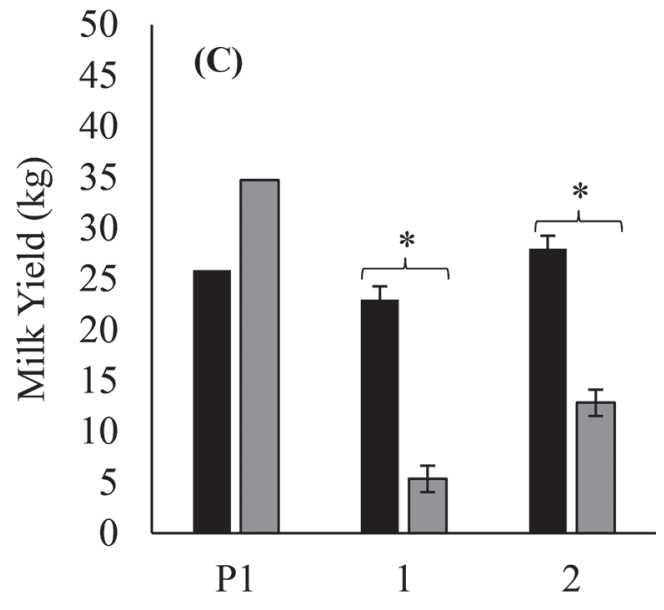

Time Relative to Bolus (d)

\section{-IL-CON $\square I L-L P S$}

Figure 1. (A) Rectal temperature, (B) DMI, and (C) milk yield from hyperlipidemic (induced via intralipid infusion) late-lactation cows administered saline (IL-CON) or an LPS (IL-LPS) bolus. Data were analyzed using PROC MIXED and included fixed effects of treatment, time, and their interaction. In $(\mathrm{A})$, treatment: $P=0.01$, time: $P>0.17$, and treatment $\times$ time: $P=0.08$; in $(\mathrm{B})$, treatment: $P=0.01$, time: $P<$ 0.01, and treatment $\times$ time: $P<0.01$; in $(\mathrm{C})$, treatment: $P<0.01$, time: $P<0.01$, and treatment $\times$ time: $P>0.41$. P1 represents an average of measurements obtained during the $5 \mathrm{~d}$ of period 1 and was used as a covariate. Data are represented as least squares means \pm standard error of the mean and considered significant if $P \leq 0.05$ and a tendency if $0.05<P \leq 0.10 .{ }^{*}$ represents significant differences between treatments; $\dagger$ represents a tendency for a difference between treatments.

Table 2. Effects of saline or LPS infusion on milk composition in experimentally induced hyperlipidemic cows during period 2

\begin{tabular}{|c|c|c|c|c|c|c|}
\hline Parameter & \multicolumn{2}{|c|}{ Treatment $^{1}$} & SEM & \multicolumn{3}{|c|}{$P$-value } \\
\hline Fat (\%) & 4.12 & 6.92 & 0.50 & $<0.01$ & 0.01 & 0.11 \\
\hline Protein $(\%)$ & 3.09 & 4.16 & 0.21 & 0.01 & $<0.01$ & 0.08 \\
\hline MUN (mg/dL) & 13.72 & 16.99 & 0.93 & 0.04 & $<0.01$ & $<0.01$ \\
\hline SCC $(\times 1,000)$ & 89 & 620 & 348 & 0.39 & 0.34 & 0.35 \\
\hline
\end{tabular}

${ }^{1} \mathrm{IL}-\mathrm{CON}=$ intralipid infused, saline; IL-LPS = intralipid infused, LPS bolus. 


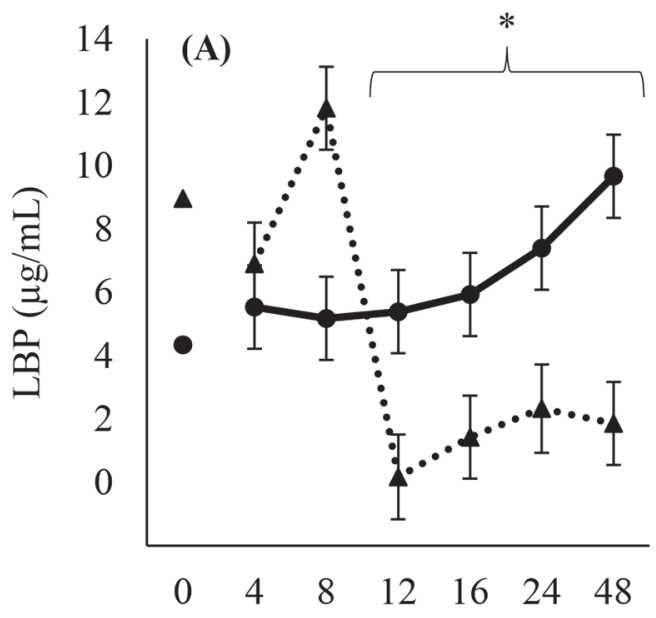

Time Relative to Bolus (h)

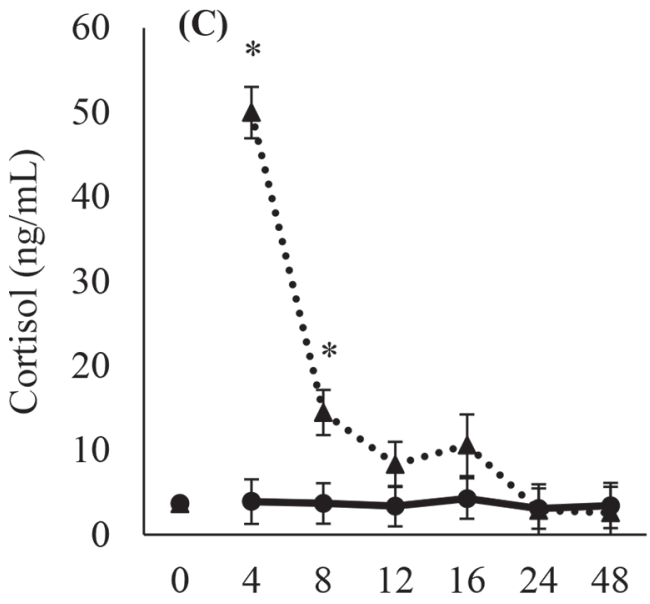

Time Relative to Bolus (h)

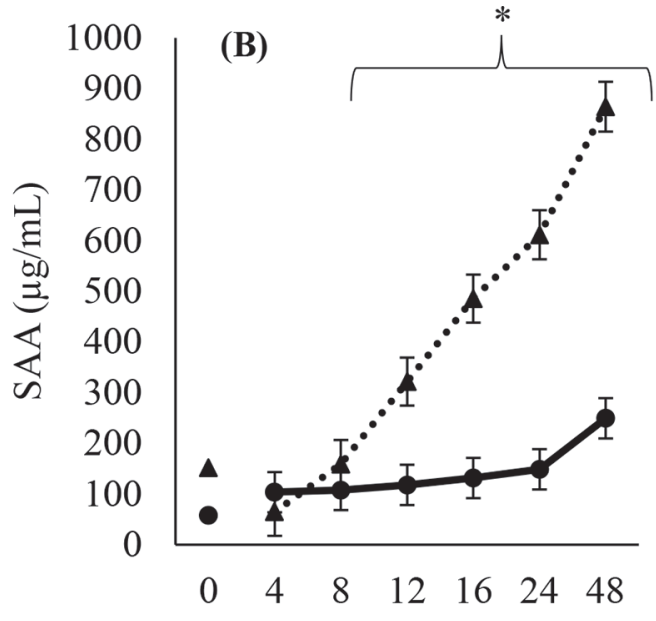

Time Relative to Bolus (h)

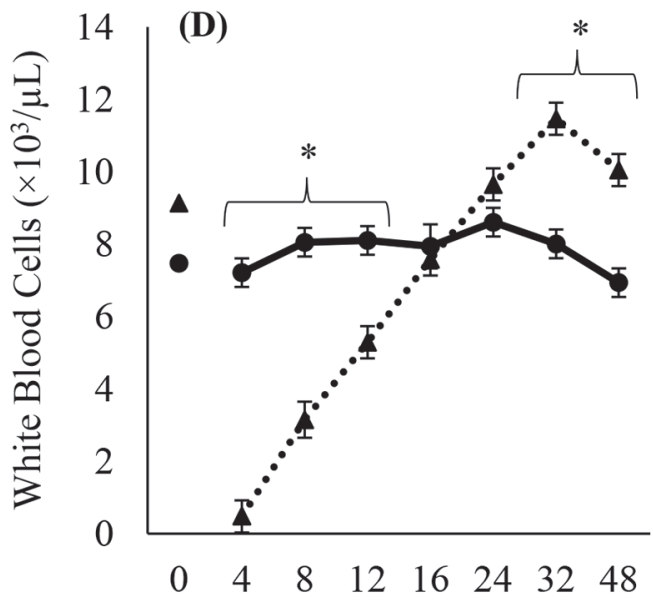

Time Relative to Bolus (h)

\section{一IL-CON $\cdots . . \cdot$ IL-LPS}

Figure 2. Circulating (A) LPS-binding protein (LBP), (B) serum amyloid A (SAA), (C) cortisol, and (D) white blood cell counts from hyperlipidemic (induced via intralipid infusion) late-lactation cows administered saline (IL-CON) or an LPS (IL-LPS) bolus. Data were analyzed using PROC MIXED and included fixed effects of treatment, time, and their interaction. In (A), treatment: $P>0.22$, time: $P<0.01$, and treatment $\times$ time: $P<0.01$; in $(\mathrm{B})$, treatment: $P<0.01$, time: $P<0.01$, and treatment $\times$ time: $P<0.01$; in $(\mathrm{C})$, treatment: $P<0.01$, time: $P<0.01$, and treatment $\times$ time: $P<0.01$; in $(\mathrm{D})$, treatment: $P<0.01$, time: $P<0.01$, and treatment $\times$ time: $P<0.01$. Hour 0 represents an average of measurements obtained before LPS administration $(-0.5$ and $0 \mathrm{~h})$ and was used as a covariate. Data are represented as least squares means \pm standard error of the mean and considered significant if $P \leq 0.05$ and a tendency if $0.05<P \leq 0.10$. ${ }^{*}$ represents significant differences between treatments.

Table 3. Effects of saline or LPS infusion on complete blood count parameters in experimentally induced hyperlipidemic cows during period 2

\begin{tabular}{|c|c|c|c|c|c|c|}
\hline Parameter & \multicolumn{2}{|c|}{ Treatment $^{1}$} & SEM & \multicolumn{3}{|c|}{$P$-value } \\
\hline Neutrophils $\left(\times 10^{3} / \mu \mathrm{L}\right)$ & 3.42 & 4.22 & 0.19 & 0.02 & $<0.01$ & $<0.01$ \\
\hline Monocytes $\left(\times 10^{3} / \mu \mathrm{L}\right)$ & 0.29 & 0.14 & 0.02 & 0.01 & $<0.01$ & 0.02 \\
\hline Lymphocytes $\left(\times 10^{3} / \mu \mathrm{L}\right)$ & 2.98 & 1.76 & 0.22 & $<0.01$ & 0.02 & $<0.01$ \\
\hline Basophils $\left(\times 10^{3} / \mu \mathrm{L}\right)$ & 0.05 & 0.03 & 0.01 & 0.12 & $<0.01$ & $<0.01$ \\
\hline
\end{tabular}

${ }^{1} \mathrm{IL}-\mathrm{CON}=$ intralipid infused, saline; IL-LPS = intralipid infused, LPS bolus. 
CON cows. During lipid infusion, serum TG increased in both treatments relative to baseline $(P<0.01)$, and LPS administration exacerbated the increase (1.5-fold increase relative to IL-CON; $P<0.01$; Figure 3B). Relative to baseline, IL infusion tended to increase liver TG content in IL-CON cows at $16 \mathrm{~h}(36 \%$; $P=$ $0.09)$, but no difference was observed in cows previously exposed to LPS $(P>0.50)$. Overall during P2, liver fat content from IL-LPS cows tended to be decreased $(25 \%)$ relative to controls $(P=0.06)$, and the largest difference was observed at $16 \mathrm{~h}$ of lipid infusion $(34 \%$ decrease relative to controls; $P=0.03$; Figure $3 \mathrm{C}$ ).

A treatment by time interaction was observed for circulating glucose such that concentrations from LPS cows decreased ( $17 \%$ relative to controls) at $8 \mathrm{~h}$ after bolus then gradually increased, whereas in control cows, concentrations remained similar $(P=0.02$; Figure $4 \mathrm{~A})$. Transient hyperinsulinemia was observed following LPS administration; concentrations peaked at $4 \mathrm{~h}$ after bolus (2- and 4-fold relative to P1 and controls, respectively),

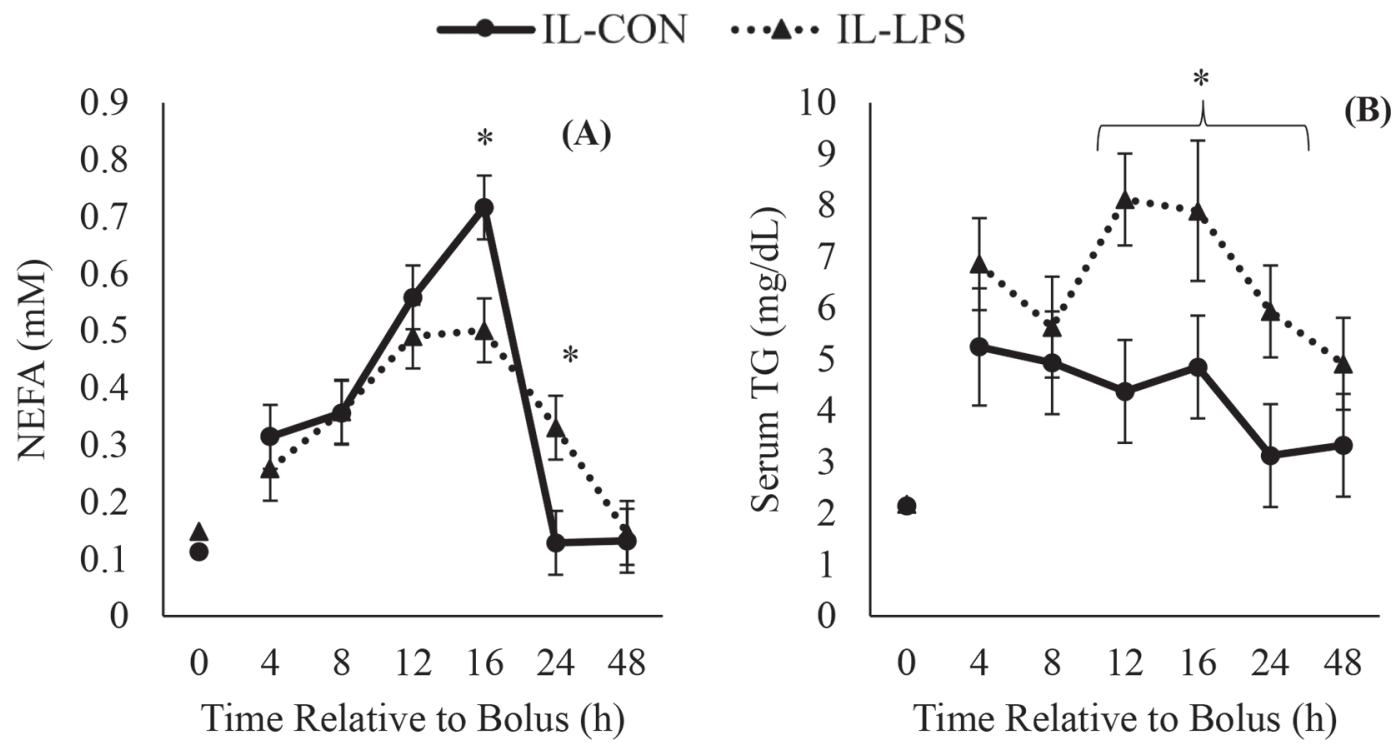

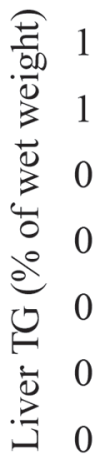

(C)

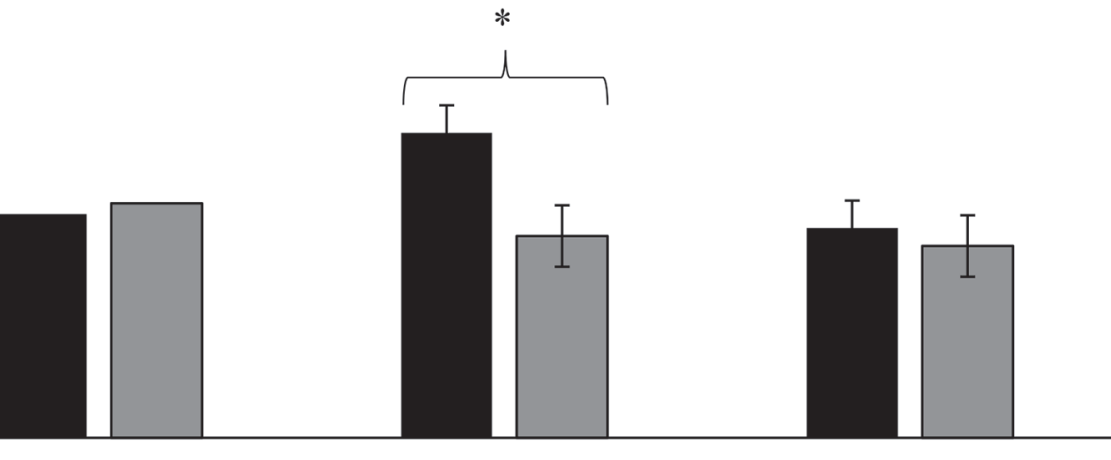

P1

16

48

Time Relative to Bolus (h)

चIL-CON $\quad$ IIL-LPS

Figure 3. (A) Circulating nonesterified fatty acids (NEFA), (B) serum triglycerides (TG), and (C) liver TG content from hyperlipidemic (induced via intralipid infusion) late-lactation cows administered saline (IL-CON) or an LPS (IL-LPS) bolus. Data were analyzed using PROC MIXED and included fixed effects of treatment, time, and their interaction. In (A), treatment: $P>0.67$, time: $P<0.01$, and treatment $\times$ time: $P=0.01$; in $(\mathrm{B})$, treatment: $P<0.01$, time: $P>0.15$, and treatment $\times$ time: $P>0.56$; in $(\mathrm{C})$, treatment: $P=0.06$, time: $P=0.09$, and treatment $\times$ time: $P=0.17$. Hour 0 represents an average of measurements obtained before LPS administration $(-0.5$ and $0 \mathrm{~h})$ and was used as a covariate for NEFA and TG. P1 represents the liver TG on d 1 of period 1 and was used as a covariate. Data are represented as least squares means \pm standard error of the mean and considered significant if $P \leq 0.05$ and a tendency if $0.05<P \leq 0.10$. ${ }^{*}$ represents significant differences between treatments. 
then gradually declined reaching $\mathrm{P} 1$ values at $16 \mathrm{~h}$ after bolus $(P<0.01)$. At $24 \mathrm{~h}$, insulin concentrations from LPS cows were decreased $(46 \%)$ relative to controls $(P$ $<0.01$; Figure 4B). Overall, circulating glucagon did not differ due to treatment $(P=0.34$; Figure $4 \mathrm{C})$, but when only h 8 through 12 were evaluated, glucagon increased (3-fold) in LPS cows relative to controls $(P=$ 0.03). Blood urea nitrogen increased in both treatments during the first $24 \mathrm{~h}$ of $\mathrm{P} 2$, after which it remained elevated $(36 \%)$ in LPS cows, whereas in controls, it returned to baseline $(P<0.01 ;$ Figure $4 \mathrm{D})$. During the first $8 \mathrm{~h}$ of lipid infusion, BHB concentrations tended to decrease in both treatments relative to baseline (26\%; $P \leq 0.07$; Figure 4E). Administration of LPS markedly decreased ionized calcium $(43 \%)$ at $12 \mathrm{~h}$ after bolus relative to control cows, after which it gradually returned to baseline $(P<0.01$; data not shown $)$. No effects of IL infusion were observed on ionized Ca from IL-CON cows $(P>0.70$; data not shown).

\section{DISCUSSION}

Excessive adipose tissue mobilization has traditionally been considered the causative factor leading to ketosis and fatty liver in poorly transitioning cows (Grummer, 1993; Drackley, 1999; Oetzel, 2004). A cornerstone of this dogma is that ruminants have a limited capacity to export TG as very low density lipoproteins (Kleppe et al., 1988). However, increasing evidence suggests that inflammation may be an etiological prerequisite for these disorders (Ametaj et al., 2005; Bertoni et al., 2006; Eckel and Ametaj, 2016); a scenario supported by human and rodent models indicating that inflammation causes hepatic steatosis (Endo et al., 2007; Ilan, 2012; Ceccarelli et al., 2015). Almost all transition cows experience some degree of inflammation immediately postpartum (Humblet et al., 2006; Bertoni et al., 2008), and the magnitude and persistency of the inflammatory state is predictive of transition-cow performance (Ohtsuka et al., 2001; Ametaj et al., 2005; Abuajamieh et al., 2016). The severity of the ensuing inflammatory response is ostensibly dependent on the frequency and type of immune insults encountered (Bertoni et al., 2008; Bradford et al., 2015; Trevisi and Minuti, 2018). Increased liver fat accumulation has been previously observed in late- and early-lactation cows in response to intravenous TNF- $\alpha$ (Bradford et al., 2009) and intramammary LPS infusion (Graugnard et al., 2013; Minuti et al., 2015). However, we were unable to reproduce fatty liver in inflamed mid-lactation cows (Horst et al., 2019b). A limitation to our previous model is the lack of a biologically meaningful and simultaneous increase in circulating NEFA (and the corresponding hepatic NEFA uptake) that naturally occurs in the periparturient cow. Therefore, this study aimed to create a more appropriate model of periparturient inflammation by inducing hyperlipidemia immediately following LPS administration in mid-lactation cows. Alternative models would have been to achieve a steady state of hyperlipidemia before immune activation or a plateaued inflammatory state before lipid infusion, but the appropriate chronological sequence of the model remains in flux.

Administering LPS induced a systemic inflammatory response herein, as indicated by mild hyperthermia, altered immune cell dynamics, hypercortisolemia, increased acute-phase proteins, and decreased production performance. Furthermore, NEFA concentrations increased in both control and immune-activated cows during the $16 \mathrm{~h}$ of continuous IL infusion, indicating experimental treatments were successfully implemented. Although IL infusion increased NEFA, the pattern observed in both treatments differed from previous lipid infusion studies, which observed a rapid increase in NEFA followed by a steady state within approximately 3 h (Burdick Sanchez et al., 2015; Caixeta et al., 2017; Lamp et al., 2018). Discrepancies in the NEFA pattern may be explained by differences in energetic state, as all cows were fasted during the lipid infusion period herein. As expected, we observed a mild increase in hepatic TG content in IL-CON cows after $16 \mathrm{~h}$ of IL infusion, but it was moderate when compared with previous reports in nonlactating cows (Caixeta et al., 2017; Rico et al., 2018) and remained below the threshold of mild fatty liver (1-5\% TG; Bobe et al., 2004). During lactation, the mammary gland is an alternative sink of blood TG and NEFA, which may partially explain why we did not detect a similar increase in the magnitude of liver lipid as was previously reported in dry cows (Caixeta et al., 2017). Regardless and in stark contrast to our hypothesis, acute systemic inflammation did not exacerbate liver fat accumulation compared with controls, which is ostensibly explained by insufficient hepatic NEFA delivery (other potential explanations are discussed below).

Circulating NEFA from LPS cows reached steady state concentrations of approximately $0.5 \mathrm{mmol} / \mathrm{L}$ at $12 \mathrm{~h}$ after the start of lipid infusion. Although NEFA concentrations exceeded levels observed in our previous LPS reports (Kvidera et al., 2017; Horst et al., 2018, 2019a,b), they did not reach levels typically observed in periparturient cows experiencing fatty liver (Bobe et al., 2004; Ametaj et al., 2005). Potential factors contributing to the blunted response may include less endogenous NEFA and reduced circulating TG hydrolysis. Administrating LPS increases circulating 

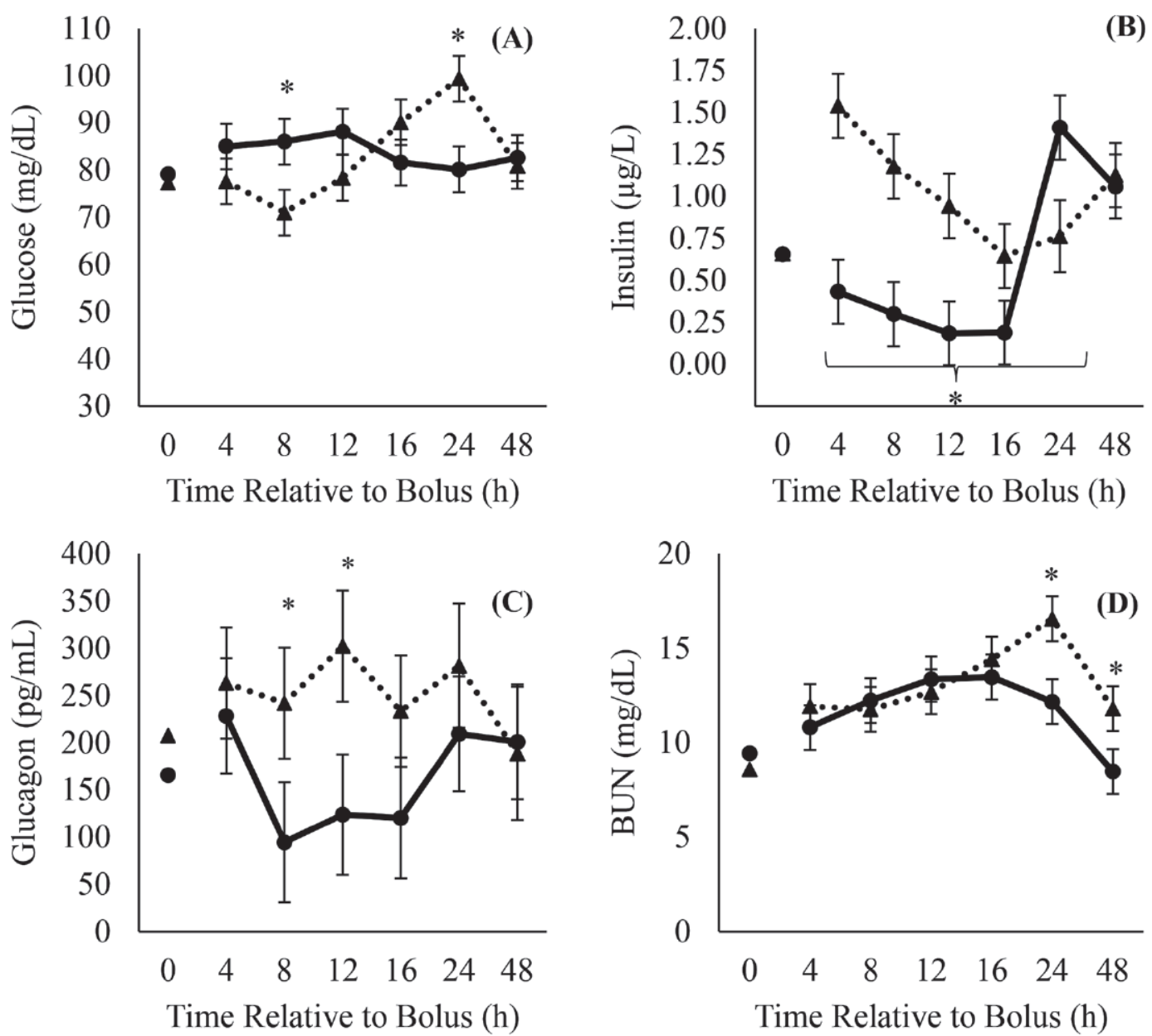

Time Relative to Bolus (h)

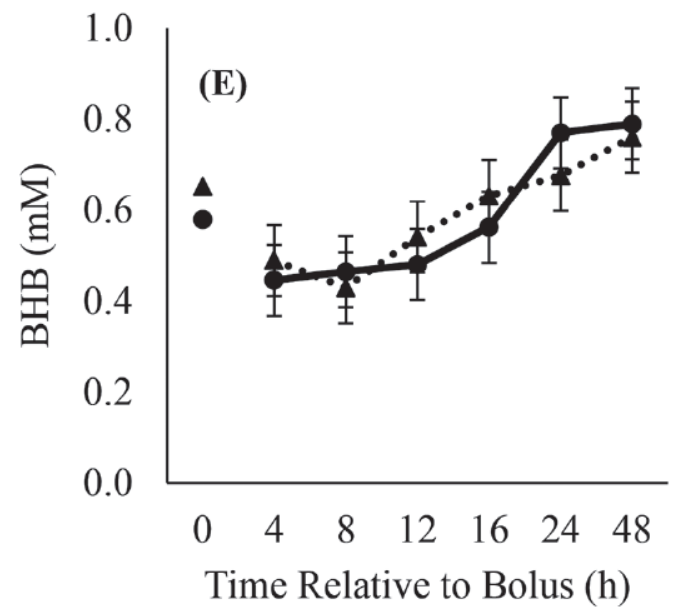

$\longrightarrow$-IL-CON $\cdots \cdot \cdot \cdot$ IL-LPS

Figure 4. Circulating (A) glucose, (B) insulin, (C) glucagon, (D) BUN, and (E) BHB from hyperlipidemic (induced via intralipid infusion) late-lactation cows administered saline (IL-CON) or an LPS (IL-LPS) bolus. Data were analyzed using PROC MIXED and included fixed effects of treatment, time, and their interaction. In $(\mathrm{A})$, treatment: $P>0.79$, time: $P<0.29$, and treatment $\times$ time: $P=0.02$; in $(\mathrm{B})$, treatment: $P<$ 0.01, time: $P<0.01$, and treatment $\times$ time: $P<0.01$; in $(\mathrm{C})$, treatment: $P>0.23$, time: $P=0.05$, and treatment $\times$ time: $P>0.34$; in $(\mathrm{D})$, treatment: $P>0.39$, time: $P<0.01$, and treatment $\times$ time: $P<0.01$; and in (E), treatment: $P>0.97$, time: $P<0.01$, and treatment $\times$ time: $P>0.19$. Hour 0 represents an average of measurements obtained before LPS administration $(-0.5$ and 0 h) and was used as a covariate. Data are represented as least squares means \pm standard error of the mean and considered significant if $P \leq 0.05$ and a tendency if $0.05<P \leq 0.10$. * represents significant differences between treatments. 
NEFA, but the response is delayed and dampened in comparison to noninflamed animals on the same plane of nutrition (Horst et al., 2018); therefore, contribution of adipose tissue mobilization to circulating NEFA was presumably less than in controls. Reasons for blunted adipose tissue lipolysis are most likely explained by LPS-induced immediate reduction in milk synthesis and LPS-induced hyperinsulinemia. LPS may have reduced hydrolysis of TG in the infused lipid emulsion. The IL solution contains TG-rich particles similar in size to chylomicrons (Samra et al., 1998) and these particles are hydrolyzed to glycerol and free fatty acids by lipoprotein lipase (LPL). However, LPL activity is decreased in response to LPS in rodents and pigs (Sakaguchi and Sakaguchi, 1979; Kawakami and Cerami, 1981; Feingold et al., 1992), a metabolic scenario leading to hypertriglyceridemia. We observed increased serum TG in both treatments in response to lipid infusion; however, the magnitude of increase was 1.5fold greater in LPS-administered cows. This suggests a greater proportion of the lipid administered in LPS cows was not hydrolyzed to NEFA; consequently, rates of hepatic NEFA uptake were presumably less than controls. It is of interest for future studies to evaluate the chronic effects of hyperlipidemia or direct NEFA infusion on hepatic lipid accumulation during immune activation to get the increase necessary to alter liver fat trafficking.

Hypertriglyceridemia is a well-characterized response to infection in monogastrics that develops as a result of reduced TG clearance and increased hepatic TG production (Blackburn, 1977; Grunfeld and Feingold, 1992; Memon et al., 1992). Increased circulating TG allow for LPS detoxification via an anti-inflammatory pathway (Read et al., 1995; Vreugdenhil et al., 2003; Barcia and Harris, 2005). Although hypertriglyceridemia has been well-described in monogastric animals, it remains largely unexplored in immune-activated ruminants, and the limited results that do exist have been inconsistent with both increased (Steiger et al., 1999; Ballou et al., 2008; Graugnard et al., 2013) and decreased (Wang et al., 2017) circulating TG being reported. Discrepancies may be explained by sampling time as the response appears to be short-lived (Steiger et al., 1999; Ballou et al., 2008; Graugnard et al., 2013). It is of interest to further investigate if infection-induced hypertriglyceridemia occurs in ruminants and if clearance rate or production (or both) is responsible. Whether or not hypertriglyceridemia would naturally occur in a ruminant, our results suggest lipid infusion in LPS-administered cows may mimic this immune-metabolic phenomenon. Therefore, we presume that many of the metabolic and inflammatory effects we observed (discussed below) are a consequence of increased TG-mediated LPS detoxification.

Perhaps one of the most intriguing results of our study was the markedly different pattern in circulating LBP in response to LPS. In contrast to previous LPS infusion studies, which demonstrate a continuous increase in LBP for $\sim 24 \mathrm{~h}$ (Horst et al., 2018, 2019a, 2020), we observed an abrupt decrease below baseline values at $12 \mathrm{~h}$ after LPS infusion. Interestingly, this decrease occurred concurrently with the NEFA plateau and peak TG concentrations. Presumably, TG-rich lipoproteins bound LPS monomers (with the help of LBP and soluble cluster of differentiation 14) and prevented LPS binding to leukocyte toll-like receptor 4 (TLR4), as has been previously demonstrated in vitro (Vreugdenhil et al., 2003). In rodents, LBP and SAA facilitate the formation of lipoprotein-LPS complexes, a process described in detail by Berbée et al. (2005). In brief, LBP transfers LPS monomers to acute-phase lipoproteins, which are formed after the displacement of apolipoproteins by SAA. Lipoprotein-LPS complexes are taken up by the liver for biliary excretion and this process may be an additional factor leading to LPSinduced increases in hepatic TG (Eckel and Ametaj, 2016). If IL infusion increased the formation of lipoprotein-LPS complexes it is reasonable to assume that this would have increased liver TG content, however, the rate at which these complexes are cleared by the liver is not well understood and differs between different lipoprotein classes (Vreugdenhil et al., 2003). Regardless, the unusual and dramatic reduction in LBP most likely represents a decrease in unbound LBP (i.e., not bound to LPS) levels (Pearce et al., 2014) as a result of increased association with lipoproteins. Little literature exists on the effects of hypertriglyceridemia on SAA and LBP concentrations, however, lipoprotein infusion reduces cytokine concentrations in mice (Levine et al., 1993), rabbits (Hubsch et al., 1995; Casas et al., 1996), dogs (Quezado et al., 1995), and steers (Burdick Sanchez et al., 2015) and increases survivability to endotoxin in rats (Read et al., 1995). Thus, TG infusion may represent a potential therapeutic approach to mitigate the negative consequences of infection.

Across species, several well-conserved metabolic alterations are employed during immune activation to meet the energetic requirements of leukocytes (Filkins, 1978; Lanza-Jacoby et al., 1998; McGuinness, 2005), and these have been described in detail in our previous ruminant publications (Kvidera et al., 2017; Horst et al., 2018, 2019a,b, 2020). In brief, a biphasic response in circulating glucose is observed in response to LPS with an initial period of hyperglycemia followed by hypoglycemia (Kvidera et al., 2017; Horst et al., 2018, 2019a). 
During the hyperglycemic phase, glucose appearance from glycogenolysis and gluconeogenesis outweighs leukocyte glucose consumption, but, within $\sim 2$ h leukocyte glucose utilization predominates and hypoglycemia develops. Because it was not a primary objective, we did not collect samples during what would be the initial hyperglycemic phase; however, we did observe decreased glucose concentrations after LPS administration. Upon activation, leukocytes increase their reliance on insulin as the driving force for glucose uptake (Calder et al., 2007), which may partially explain the marked hyperinsulinemia that develops in response to LPS (Waldron et al., 2003; Zarrin et al., 2014; Kvidera et al., 2017). Furthermore, LPS may act directly on the pancreas to increase insulin secretion as we have recently described (Baumgard et al., 2016). Interestingly, the pattern of circulating insulin in response to LPS was markedly different from our previous reports (Kvidera et al., 2017; Horst et al., 2018); specifically, it peaked earlier and declined faster during the first $16 \mathrm{~h}$ after LPS. This peculiar pattern may be explained by a dampened immune response as a result of lipoprotein-LPS detoxification. It is of interest to further evaluate the connection between increased lipid, LPS concentrations, and insulin secretion. In agreement with previous experiments (Horst et al., 2019a), LPS increased circulating glucagon which is a potent stimulator of glycogenolysis and gluconeogenesis, thereby (presumably) providing additional glucose for leukocyte use. Furthermore, we observed a continued increase in circulating BUN in the LPS cows following termination of IL infusion relative to controls. Muscle catabolism is a critical strategy for providing gluconeogenic precursors under fasting conditions. However, in immune-activated animals, amino acid mobilization is exaggerated due to increased glucose requirements of activated leukocytes (Kvidera et al., 2017; Horst et al., 2018) and the synthesis of acutephase proteins (Klasing and Austic, 1984).

As alluded to earlier, many of the metabolic changes described in response to LPS closely resemble observations in poorly transitioning cows. However, a key dissimilarity between these 2 situations is the absence of hyperketonemia in the LPS-administered cow. In response to LPS, circulating ketones are markedly decreased in ruminants (Waldron et al., 2003; Graugnard et al., 2013; Kvidera et al., 2017) and the mechanisms mediating this decrease remain poorly understood. In rodents, LPS administration reduces hepatic ketogenesis (Takeyama et al., 1990; Maitra et al., 2009), but in ruminants LPS had no effect (Waldron et al., 2003), however this was evaluated in mid-lactation cows that lacked high NEFA concentrations, one variable required for ketogenesis. Lipid infusion has been shown to increase BHB concentrations in previous studies (Chelikani et al., 2003; Caixeta et al., 2017); however, the NEFA load administered herein was presumably insufficient to increase ketones. In fact, we observed decreased BHB concentrations in both treatments during the infusion period. Because feed was removed from both treatments during the infusion period, the response probably resulted from a decrease in ketone production by the rumen epithelium, which is the primary source of ketones in the well-fed ruminant (Pennington, 1952). Regardless, a better understanding of inflammation's role in ketone metabolism has obvious implications to the transition dairy cow.

Although we believe that insufficient hepatic NEFA delivery may partially explain why inflammation did not exacerbate liver fat accumulation herein, other potential explanations need consideration. First, transition cows are exposed to chronic inflammation that can persist for several weeks (Bionaz et al., 2007; Bertoni et al., 2009; Abuajamieh et al., 2016), whereas our study modeled an acute inflammatory response. Throughout the transition period, cows are exposed to a myriad of inflammation-inducing events of both biotic and abiotic origin, and repeated exposures interfere with inflammation resolution and hepatic phenotypes (Trevisi and Minuti, 2018). A single LPS bolus or even continuous LPS infusion (accompanied by tolerance) may not surpass the inflammatory threshold necessary to lead to the dysregulated response. A second important consideration is differences in systemic versus compartmentalized inflammation. Intestinally derived endotoxin, which escapes gut defense mechanisms, enters the portal vein for delivery to the liver, the major LPS-detoxifying organ (as reviewed by Guerville and Boudry, 2016). If the liver's capacity to neutralize endotoxin is not overwhelmed, endotoxemia is prevented, but systemic inflammation still occurs (Ogden et al., 2020). In this scenario, LPS is prevented from binding to extrasplanchnic tissues, including mammary epithelial cells that contain TLR4 receptors (Ibeagha-Awemu et al., 2008). Pro-inflammatory cytokines (at least TNF- $\alpha$ ) do not appear to meaningfully reduce milk synthesis (Bradford et al., 2009; Martel et al., 2014). Thus, alimentary tract and hepatic immune activation might not directly inhibit milk synthesis, and thus, the mammary gland's nutrient requirement remains robust. In contrast, LPS administered via the jugular vein obviously causes acute systemic endotoxemia, and LPS binding to mammary epithelial cell TLR4 receptors causes an immediate decrease in milk synthesis in vitro (Liu et al., 2015) and in vivo (Kvidera et al., 2017; Horst et al., 2018). This proposed mechanism may partially explain why adipose tissue mobilization from 
LPS-administered cows is blunted when compared with healthy cows on the same plane of nutrition (i.e., the metabolic demands of milk synthesis markedly differ).

\section{CONCLUSIONS}

In conclusion, experimentally induced hyperlipidemia (induced by IL infusion) during acute systemic inflammation did not exacerbate fatty liver in latelactation cows as we hypothesized. However, infusing lipid following LPS administration markedly altered the characteristic patterns of circulating insulin and LBP, changes we believe are reflective of dampened immune activation. Developing a more accurate model of transition-cow inflammation (i.e., chronic response) is a prerequisite to understanding how (or if) the immune system and immunometabolism contribute to hepatic steatosis.

\section{ACKNOWLEDGMENTS}

This project was supported by the Agricultural and Food Research Initiative Competitive Grant no. 201705931 from the USDA National Institute of Food and Agriculture (Kansas City, MO). The authors have not stated any conflicts of interest.

\section{REFERENCES}

Abuajamieh, M., S. K. Kvidera, M. V. Sanz Fernandez, A. Nayeri, N. C. Upah, E. A. Nolan, S. M. Lei, J. M. DeFrain, H. B. Green, K. M. Schoenberg, W. E. Trout, and L. H. Baumgard. 2016. Inflammatory biomarkers are associated with ketosis in periparturient Holstein cows. Res. Vet. Sci. 109:81-85. https://doi.org/10.1016/ j.rvsc.2016.09.015.

Ametaj, B. N., B. J. Bradford, G. Bobe, R. A. Nafikov, Y. Lu, J. W. Young, and D. C. Beitz. 2005. Strong relationships between mediators of the acute phase response and fatty liver in dairy cows. Can. J. Anim. Sci. 85:165-175. https://doi.org/10.4141/A04-043.

Ametaj, B. N., Q. Zebeli, and S. Iqbal. 2010. Nutrition, microbiota, and endotoxin-related diseases in dairy cows. Rev. Bras. Zootec. 39(suppl spe):433-444. https://doi.org/10.1590/S1516 $-35982010001300048$.

AOAC International. 1995. AOAC official method 972.16. Fat, lactose, protein, and solids in milk. Mid infrared spectroscopic method. Pages 23-26 in Official Methods of Analysis. 16th ed. Vol. 2. AOAC International, Arlington, VA.

Baird, G. D. 1982. Primary ketosis in the high-producing dairy cow: Clinical and subclinical disorders, treatment, prevention, and outlook. J. Dairy Sci. 65:1-10. https://doi.org/10.3168/jds.S0022 -0302(82)82146-2.

Ballou, M. A., G. D. Cruz, W. Pittroff, D. H. Keisler, and E. J. DePeters. 2008. Modifying the acute phase response of Jersey calves by supplementing milk replacer with omega-3 fatty acids from fish oil. J. Dairy Sci. 91:3478-3487. https://doi.org/10.3168/ jds.2008-1016.

Barcia, A. M., and H. W. Harris. 2005. Triglyceride-rich lipoproteins as agents of innate immunity. Clin. Infect. Dis. 41(Supplement_7):S498-S503. https://doi.org/10.1086/432005.

Bauman, D. E., and W. B. Currie. 1980. Partitioning of nutrients during pregnancy and lactation: A review of mechanisms involving homeostasis and homeorhesis. J. Dairy Sci. 63:1514-1529. https:// doi.org/10.3168/jds.S0022-0302(80)83111-0.

Baumgard, L. H., G. J. Hausman, and M. V. Sanz Fernandez. 2016. Insulin: Pancreatic secretion and adipocyte regulation. Domest. Anim. Endocrinol. 54:76-84. https://doi.org/10.1016/j.domaniend 2015.07.001.

Berbée, J. F. P., L. M. Havekes, and P. C. N. Rensen. 2005. Apolipoproteins modulate the inflammatory response to lipopolysaccharide. J. Endotoxin. Research 11:97-103. https://doi.org/10.1177/ 09680519050110020501.

Bertoni, G., E. Trevisi, L. Calamari, and M. Bionaz. 2006. The inflammation could have a role in the liver lipidosis occurrence in dairy cows. Pages 157-158 in Production Diseases in Farm Animals. 12th International Conference. N. Joshi and T. H. Herdt, ed. Wageningen Academic Publishers, Wageningen, the Netherlands.

Bertoni, G., E. Trevisi, X. Han, and M. Bionaz. 2008. Effects of inflammatory conditions on liver activity in puerperium period and consequences for performance in dairy cows. J. Dairy Sci. 91:33003310. https://doi.org/10.3168/jds.2008-0995.

Bertoni, G., E. Trevisi, and R. Lombardelli. 2009. Some new aspects of nutrition, health conditions and fertility of intensively reared dairy cows. Ital. J. Anim. Sci. 8:491-518. https://doi.org/10.4081/ ijas.2009.491.

Bionaz, M., E. Trevisi, L. Calamari, F. Librandi, A. Ferrari, and G. Bertoni. 2007. Plasma paraoxonase, health, inflammatory conditions, and liver function in transition dairy cows. J. Dairy Sci 90:1740-1750. https://doi.org/10.3168/jds.2006-445.

Blackburn, G. L. 1977. Lipid metabolism in infection. Am. J. Clin. Nutr. 30:1321-1332. https://doi.org/10.1093/ajcn/30.8.1321.

Bobe, G., J. W. Young, and D. C. Beitz. 2004. Invited Review: Pathology, etiology, prevention, and treatment of fatty liver in dairy cows. J. Dairy Sci. 87:3105-3124. https://doi.org/10.3168/jds .S0022-0302(04)73446-3.

Bradford, B. J., L. K. Mamedova, J. E. Minton, J. S. Drouillard, and B. J. Johnson. 2009. Daily injection of tumor necrosis factor-a increases hepatic triglycerides and alters transcript abundance of metabolic genes in lactating dairy cattle. J. Nutr. 139:1451-1456. https://doi.org/10.3945/jn.109.108233.

Bradford, B. J., K. Yuan, J. K. Farney, L. K. Mamedova, and A. J. Carpenter. 2015. Invited review: Inflammation during the transition to lactation: New adventures with an old flame. J. Dairy Sci. 98:6631-6650. https://doi.org/10.3168/jds.2015-9683.

Burdick Sanchez, N. C., J. A. Carroll, J. R. Donaldson, J. O. Buntyn, and T. B. Schmidt. 2015. Exogenous administration of lipid to steers alters aspects of the innate immune response to endotoxin challenge. Innate Immun. 21:512-522. https://doi.org/10.1177/ 1753425914552741.

Caixeta, L. S., S. L. Giesy, C. S. Krumm, J. W. Perfield 2nd, A. Butterfield, K. M. Schoenberg, D. C. Beitz, and T. R. Boisclair. 2017. Effects of circulating glucagon and free fatty acids on hepatic FGF21 production in dairy cows. Am. J. Physiol. Regul. Integr. Comp. Physiol. 313:R526-R534. https://doi.org/10.1152/ajpregu .00197 .2017 .

Calder, P. C., G. Dimitriadis, and P. Newsholme. 2007. Glucose metabolism in lymphoid and inflammatory cells and tissues. Curr. Opin. Clin. Nutr. Metab. Care 10:531-540. https://doi.org/10 .1097/MCO.0b013e3281e72ad4.

Casas, A. T., A. P. Hubsch, and J. E. Doran. 1996. Effects of reconstituted high-density lipoprotein in persistent gram-negative bacteremia. Am. Surg. 62:350-355.

Ceccarelli, S., N. Panera, M. Mina, D. Gnani, C. De Stefanis, A. Crudele, C. Rychlicki, S. Petrini, G. Bruscalupi, L. Agostinelli, L. Stronati, S. Cucchiara, G. Musso, C. Furlanello, G. SvegliatiBaroni, V. Nobili, and A. Alisi. 2015. LPS-induced TNF- $\alpha$ factor mediates pro-inflammatory and pro-fibrogenic pattern in non-alcoholic fatty liver disease. Oncotarget 6:41434-41452. https://doi .org/10.18632/oncotarget.5163.

Chelikani, P. K., D. H. Keisler, and J. J. Kennelly. 2003. Response of plasma leptin concentration to jugular infusion of glucose or lipid is dependent on the stage of lactation of Holstein cows. J. Nutr. 133:4163-4171. https://doi.org/10.1093/jn/133.12.4163. 
Csak, T., M. Ganz, J. Pespisa, K. Kodys, A. Dolganiuc, and G. Szabo. 2011. Fatty acid and endotoxin activate inflammasomes in mouse hepatocytes that release danger signals to stimulate immune cells. Hepatology 54:133-144. https://doi.org/10.1002/hep.24341.

Day, C. P., and O. F. W. James. 1998. Steatohepatitis: A rale of two "hits"? Gastroenterology 114:842-845. https://doi.org/10.1016/ S0016-5085(98)70599-2.

Drackley, J. K. 1999. Biology of dairy cows during the transition period: The final frontier? J. Dairy Sci. 82:2259-2273. https://doi .org/10.3168/jds.S0022-0302(99)75474-3.

Eckel, E. F., and B. N. Ametaj. 2016. Invited Review: Role of bacterial endotoxins in the etiopathogenesis of periparturient diseases of transition dairy cows. J. Dairy Sci. 99:5967-5990. https://doi.org/ 10.3168/jds.2015-10727.

Endo, M., T. Masaki, M. Seike, and H. Yoshimatsu. 2007. TNF- $\alpha$ induces hepatic steatosis in mice by enhancing gene expression of sterol regulatory element binding protein-1c (SREBP-1c). Exp. Biol. Med. (Maywood) 232:614-621.

Feingold, K. R., I. Staprans, R. A. Memon, A. H. Moser, J. K. Shigenaga, W. Doerrler, C. A. Dinarello, and C. Grunfeld. 1992. Endotoxin rapidly induces changes in lipid metabolism that produce hypertriglyceridemia: Low doses stimulate hepatic triglyceride production while high doses inhibit clearance. J. Lipid Res. $33: 1765-1776$

Filkins, J. P. 1978. Phases of glucose dyshomeostasis in endotoxicosis. Circ. Shock 5:347-355.

Graugnard, D. E., M. Bionaz, E. Trevisi, K. M. Moyes, J. L. SalakJohnson, R. L. Wallace, J. K. Drackley, G. Bertoni, and J. J. Loor. 2012. Blood immunometabolic indices and polymorphonuclear neutrophil function in peripartum dairy cows are altered by level of dietary energy prepartum. J. Dairy Sci. 95:1749-1758. https:// doi.org/10.3168/jds.2011-4579.

Graugnard, D. E., K. M. Moyes, E. Trevisi, M. J. Khan, D. Keisler, J. K. Drackley, G. Bertoni, and J. J. Loor. 2013. Liver lipid content and inflammometabolic indices in peripartal dairy cows are altered in response to prepartal energy intake and postpartal intramammary inflammatory challenge. J. Dairy Sci. 96:918-935. https:// doi.org/10.3168/jds.2012-5676.

Grummer, R. R. 1993. Etiology of lipid-related metabolic disorder in periparturient dairy cows. J. Dairy Sci. 76:3882-3896. https://doi .org/10.3168/jds.S0022-0302(93)77729-2.

Grunfeld, C., and K. R. Feingold. 1992. Tumor necrosis factor, interleukin and interferon induced changes in lipid metabolism as part of host defense. Proc. Soc. Exp. Biol. Med. 200:224-227. https:// doi.org/10.3181/00379727-200-43424.

Guerville, M., and G. Boudry. 2016. Gastrointestinal and hepatic mechanisms limiting entry and dissemination of lipopolysaccharide into the systemic circulation. Am. J. Physiol. Gastrointest. Liver Physiol. 311:G1-G15. https://doi.org/10.1152/ajpgi.00098.2016.

Hamarneh, S. R., B.-M. Kim, K. Kaliannan, S. A. Morrison, T. J. Tantillo, Q. Tao, M. M. R. Mohamed, J. M. Ramirez, A. Karas, W. Liu, D. Hu, A. Teshager, S. S. Gul, K. P. Economopoulos, A. K. Bhan, M. S. Malo, M. Y. Choi, and R. A. Hodin. 2017. Intestinal alkaline phosphatase attenuates alcohol-induced hepatosteatosis in mice. Dig. Dis. Sci. 62:2021-2034. https://doi.org/10.1007/s10620 $-017-4576-0$.

Herdt, T. H. 1988. Fatty liver in dairy cows. Vet. Clin. North Am. Food Anim. Pract. 4:269-287. https://doi.org/10.1016/S0749 -0720(15)31048-3.

Horst, E. A., S. K. Kvidera, M. J. Dickson, C. S. McCarthy, E. J. Mayorga, M. Al-Qaisi, H. A. Ramirez, A. F. Keating, and L. H. Baumgard. 2019b. Effects of continuous and increasing lipopolysaccharide infusion on basal and stimulated metabolism in lactating Holstein cows. J. Dairy Sci. 102:3584-3597. https://doi.org/10 $.3168 /$ jds.2018-15627.

Horst, E. A., S. K. Kvidera, E. J. Mayorga, C. S. Shouse, M. Al-Qaisi, M. J. Dickson, J. Ydstie, H. A. Ramirez Ramirez, A. F. Keating, D. J. Dickson, K. E. Griswold, and L. H. Baumgard. 2018. Effect of chromium on bioenergetics and leukocyte dynamics following immunoactivation in lactating Holstein cows. J. Dairy Sci. 101:5515-5530. https://doi.org/10.3168/jds.2017-13899.
Horst, E. A., E. J. Mayorga, M. Al-Qaisi, M. A. Abeyta, B. M. Goetz, H. A. Ramirez Ramirez, D. H. Kleinschmit, and L. H. Baumgard. 2019a. Effects of dietary zinc source on the metabolic and immunological response to lipopolysaccharide in lactating Holstein dairy cows. J. Dairy Sci. 102:11681-11700. https://doi.org/10.3168/jds 2019-17037.

Horst, E. A., E. J. Mayorga, M. Al-Qaisi, M. A. Abeyta, S. L. Portner, C. S. McCarthy, B. M. Goetz, S. K. Kvidera, and L. H. Baumgard. 2020. Effects of maintaining eucalcemia following immunoactivation in lactating Holstein dairy cows. J. Dairy Sci. https://doi.org/ 10.3168/jds.2020-18268 (accepted).

Hubsch, A. P., A. T. Casas, and J. E. Doran. 1995. Protective effects of reconstituted high-density lipoprotein in rabbit gram-negative bacteremia models. J. Lab. Clin. Med. 126:548-558.

Humblet, M.-F., H. Guyot, B. Boudry, F. Mbayahi, C. Hanzen, F. Rollin, and J. M. Godeau. 2006. Relationship between haptoglobin, serum amyloid A, and clinical status in a survey of dairy herds during a 6-month period. Vet. Clin. Pathol. 35:188-193. https:// doi.org/10.1111/j.1939-165X.2006.tb00112.x.

Ibeagha-Awemu, E. M., J.-W. Lee, A. E. Ibeagha, D. D. Bannerman, M. J. Paape, and X. Zhao. 2008. Bacterial lipopolysaccharide induces increased expression of toll-like receptor (TLR) 4 and downstream TLR signaling molecules in bovine mammary epithelial cells. Vet. Res. 39:11. https://doi.org/10.1051/vetres:2007047.

Ilan, Y. 2012. Leaky gut and the liver: A role for bacterial translocation in nonalcoholic steatohepatitis. World J. Gastroenterol. 18:2609-2618. https://doi.org/10.3748/wjg.v18.i21.2609.

Jia, L., X. Chang, S. Qian, C. Liu, C. C. Lord, N. Ahmed, C. E. Lee, S. Lee, L. Gautron, M. C. Mitchell, J. D. Horton, P. E. Scherer, and J. K. Elmquist. 2018. Hepatocyte toll-like receptor 4 deficiency protects against alcohol-induced fatty liver disease. Mol. Metab. 14:121-129. https://doi.org/10.1016/j.molmet.2018.05.015.

Jin, C. J., A. J. Engstler, D. Ziegenhardt, S. C. Bischoff, C. Trautwein, and I. Bergheim. 2017. Loss of lipopolysaccharide-binding protein attenuates the development of diet-induced non-alcoholic fatty liver disease in mice. J. Gastroenterol. Hepatol. 32:708-715. https://doi.org/10.1111/jgh.13488.

Kawakami, M., and A. Cerami. 1981. Studies of endotoxin-induced decrease in lipoprotein lipase activity. J. Exp. Med. 154:631-639. https://doi.org/10.1084/jem.154.3.631.

Klasing, K. C., and R. E. Austic. 1984. Changes in protein synthesis due to an inflammatory challenge. Proc. Soc. Exp. Biol. Med. 176:285-291. https://doi.org/10.3181/00379727-176-41872.

Kleppe, B. B., R. J. Aiello, R. R. Grummer, and L. E. Armentano. 1988. Triglyceride accumulation and very low density lipoprotein secretion by rat and goat hepatocytes in vitro. J. Dairy Sci. 71:1813-1822. https://doi.org/10.3168/jds.S0022-0302(88)79750 -7 .

Kvidera, S. K., E. A. Horst, M. Abuajamieh, E. J. Mayorga, M. V. Sanz Fernandez, and L. H. Baumgard. 2017. Glucose requirements of an activated immune system in lactating Holstein cows. J. Dairy Sci. 100:2360-2374. https://doi.org/10.3168/jds.2016-12001.

Lamp, O., H. Reyer, W. Otten, G. Nürnberg, M. Derno, K. Wimmers, C. C. Metges, and B. Kuhla. 2018. Intravenous lipid infusion affects dry matter intake, methane yield, and rumen bacteria structure in late-lactating Holstein cows. J. Dairy Sci. 101:6032-6046. https://doi.org/10.3168/jds.2017-14101.

Lanza-Jacoby, S., H. Phetteplace, N. Sedkova, and G. Knee. 1998. Sequential alterations in tissue lipoprotein lipase, triglyceride secretion rates, and serum tumor necrosis factor a during Escherichia coli bacteremic sepsis in relation to the development of hypertriglyceridemia. Shock 9:46-51. https://doi.org/10.1097/00024382 -199801000-00007.

Lanza-Jacoby, S., and A. Tabares. 1990. Triglyceride kinetics, tissue lipoprotein lipase, and liver lipogenesis in septic rats. Am. J. Physiol. Endocrinol. Metab. 258:E678-E685. https://doi.org/10 .1152 /ajpendo.1990.258.4.E678.

Levine, D. M., T. S. Parker, T. M. Donnelly, A. Walsh, and A. L. Rubin. 1993. In vivo protection against endotoxin by plasma high density lipoprotein. Proc. Natl. Acad. Sci. USA 90:12040-12044. https://doi.org/10.1073/pnas.90.24.12040. 
Liu, L., Y. Lin, L. Liu, Y. Bian, L. Zhang, X. Gao, and Q. Li. 2015. 14$3-3 \gamma$ regulates lipopolysaccharide-induced inflammatory responses and lactation in dairy cow mammary epithelial cells by inhibiting NF- $\beta \beta$ and MAPKs and up-regulating mTOR signaling. Int. J. Mol. Sci. 16:16622-16641. https://doi.org/10.3390/ijms160716622.

Maitra, U., S. Chang, N. Singh, and L. Li. 2009. Molecular mechanism underlying the suppression of lipid oxidation during endotoxemia. Mol. Immunol. 47:420-425. https://doi.org/10.1016/j.molimm 2009.08 .023

Martel, C. A., L. K. Mamedova, J. E. Minton, M. L. Jones, J. A. Carroll, and B. J. Bradford. 2014. Continuous low-dose infusion of tumor necrosis factor alpha in adipose tissue elevates adipose tissue interleukin 10 abundance and fails to alter metabolism in lactating dairy cows. J. Dairy Sci. 97:4897-4906. https://doi.org/ 10.3168/jds.2013-7777.

McGuinness, O. P. 2005. Defective glucose homeostasis during infection. Annu. Rev. Nutr. 25:9-35. https://doi.org/10.1146/annurev .nutr.24.012003.132159.

Memon, R. A., K. R. Feingold, A. H. Moser, W. Doerrler, S. Adi, C. A. Dinarello, and C. Grunfeld. 1992. Differential effects of interleukin-1 and tumor necrosis factor on ketogenesis. Am. J. Physiol. Endocrinol. Metab. 263:E301-E309. https://doi.org/10.1152/ ajpendo.1992.263.2.E301.

Minuti, A., Z. Zhou, D. E. Graugnard, S. L. Rodriguez-Zas, A. R Palladino, F. C. Cardoso, E. Trevisi, and J. J. Loor. 2015. Acute mammary and liver transcriptome responses after an intramammary Escherichia coli lipopolysaccharide challenge in postpartal dairy cows. Physiol. Rep. 3:e12388. https://doi.org/10.14814/phy2 .12388 .

Morey, S. D., L. K. Mamedova, D. E. Anderson, C. K. Armendariz, E. C. Titgemeyer, and B. J. Bradford. 2011. Effects of encapsulated niacin on metabolism and production of periparturient dairy cows. J. Dairy Sci. 94:5090-5104. https://doi.org/10.3168/jds.2011 -4304 .

National Research Council. 2001. Nutrient Requirements of Dairy Cattle. 7th rev. ed. National Academies Press, Washington, DC.

Oetzel, G. R. 2004. Monitoring and testing dairy herds for metabolic disease. Vet. Clin. North Am. Food Anim. Pract. 20:651-674.

Ogden, H. B., R. B. Child, J. L. Fallowfield, S. K. Delves, C. S. Westwood, and J. D. Layden. 2020. The gastrointestinal exertional heat stroke paradigm: Pathophysiology, assessment, severity, aetiology and nutritional countermeasures. Nutrients 12:537. https://doi .org/10.3390/nu12020537.

Ohtsuka, H., M. Koiwa, A. Hatsugaya, K. Kudo, F. Hoshi, N. Itoh, H. Yokota, H. Okada, and S. Kawamura. 2001. Relationship between serum TNF activity and insulin resistance in dairy cows affected with naturally occurring fatty liver. J. Vet. Med. Sci. 63:10211025. https://doi.org/10.1292/jvms.63.1021.

Pearce, S. C., M. V. Sanz-Fernandez, J. H. Hollis, L. H. Baumgard, and N. K. Gabler. 2014. Short-term exposure to heat stress attenuates appetite and intestinal integrity in growing pigs. J. Anim. Sci. 92:5444-5454. https://doi.org/10.2527/jas.2014-8407.

Pennington, R. J. 1952. The metabolism of short-chain fatty acids in the sheep. 1. Fatty acid utilization and ketone body production by rumen epithelium and other tissues. Biochem. J. 51:251-258. https://doi.org/10.1042/bj0510251.

Quezado, Z. M., C. Natanson, S. M. Banks, D. W. Alling, C. A. Koev, R. L. Danner, R. J. Elin, J. M. Hosseini, T. S. Parker, and D. M. Levine. 1995. Therapeutic trial of reconstituted human high-density lipoprotein in a canine model of gram-negative septic shock. J. Pharmacol. Exp. Ther. 272:604-611.

Read, T. E., C. Grunfeld, Z. Kumwenda, M. C. Calhoun, J. P. Kane, K. R. Feingold, and J. H. Rapp. 1995. Triglyceride-rich lipoproteins improve survival when given after endotoxin in rats. Surgery 117:62-67. https://doi.org/10.1016/S0039-6060(05)80231-4.
Rhoads, M. L., J. W. Kim, R. J. Collier, B. A. Crooker, Y. R. Boisclair, L. H. Baumgard, and R. P. Rhoads. 2010. Effects of heat stress and nutrition on lactating Holstein cows: II. Aspects of hepatic growth hormone responsiveness. J. Dairy Sci. 93:170-179. https://doi.org/10.3168/jds.2009-2469.

Rico, J. E., S. L. Giesy, N. J. Haughey, Y. R. Boisclair, and J. W. McFadden. 2018. Intravenous triacylglycerol infusion promotes ceramide accumulation and hepatic steatosis in dairy cows. J. Nutr. 148:1529-1535. https://doi.org/10.1093/jn/nxy155.

Sakaguchi, O., and S. Sakaguchi. 1979. Alterations of lipid metabolism in mice injected with endotoxin. Microbiol. Immunol. 23:71-85. https://doi.org/10.1111/j.1348-0421.1979.tb00443.x.

Samra, J. S., S. L. Giles, L. K. M. Summers, R. D. Evans, P. Arner, S. M. Humphreys, L. M. Clark, and K. N. Frayn. 1998. Peripheral fat metabolism during infusion of an exogenous triacylglycerol emulsion. Int. J. Obes. Relat. Metab. Disord. 22:806-812. https://doi .org/10.1038/sj.ijo.0800664.

Steiger, M., M. Senn, G. Altreuther, D. Werling, F. Sutter, M. Kreuzer, and W. Langhans. 1999. Effect of prolonged low-dose lipopolysaccharide infusion on feed intake and metabolism in heifers. J. Anim. Sci. 77:2523-2532. https://doi.org/10.2527/1999.7792523x.

Stienstra, R., F. Saudale, C. Duval, S. Keshtkar, J. E. M. Groener, N van Rooijen, B. Staels, S. Kersten, and M. Müller. 2010. Kupffer cells promote hepatic steatosis via interleukin-1 $\beta$-dependent suppression of peroxisome proliferator-activated receptor $\alpha$ activity. Hepatology 51:511-522. https://doi.org/10.1002/hep.23337.

Takeyama, N., Y. Itoh, Y. Kitazwa, and T. Tanaka. 1990. Altered hepatic mitochondrial fatty acid oxidation and ketogenesis in endotoxic rats. Am. J Physiol. Endocrinol. Metab. 259:E498-E505. https://doi.org/10.1152/ajpendo.1990.259.4.E498.

Trevisi, E., and A. Minuti. 2018. Assessment of the innate immune response in the periparturient cow. Res. Vet. Sci. 116:47-54. https: //doi.org/10.1016/j.rvsc.2017.12.001.

Vreugdenhil, A. C. E., C. H. Rousseau, T. Hartung, J. W. M. Greve, C. van 't Veer, and W. A. Buurman. 2003. Lipopolysaccharide (LPS)binding protein mediates LPS detoxification by chylomicrons. J. Immunol. 170:1399-1405. https://doi.org/10.4049/jimmunol.170.3 .1399.

Waldron, M. R., T. Nishida, B. J. Nonnecke, and T. R. Overton. 2003. Effect of lipopolysaccharide on indices of peripheral and hepatic metabolism in lactating cows. J. Dairy Sci. 86:3447-3459. https:// doi.org/10.3168/jds.S0022-0302(03)73949-6.

Wang, L. F., S. D. Jia, G. Q. Yang, R. Y. Liu, G. Y. Yang, M. Li, H. S. Zhu, Y. Y. Wang, and L. Q. Han. 2017. The effects of acute lipopolysaccharide challenge on dairy goat liver metabolism assessed with ${ }^{1}$ HNMR metabonomics. J. Anim. Physiol. Anim. Nutr. (Berl.) 101:180-189. https://doi.org/10.1111/jpn.12439.

Zarrin, M., O. Wellnitz, H. A. van Dorland, J. J. Gross, and R. M. Bruckmaier. 2014. Hyperketonemia during lipopolysaccharide-induced mastitis affects systemic and local intramammary metabolism in dairy cows. J. Dairy Sci. 97:3531-3541. https://doi.org/10 $.3168 /$ jds.2013-7480.

\section{ORCIDS}

L. M. van den Brink @ https://orcid.org/0000-0003-0508-8649

E. J. Mayorga @ https://orcid.org/0000-0001-7673-5191

M. Al-Qaisi 으 https://orcid.org/0000-0002-0020-3428

L. S. Caixeta @ https://orcid.org/0000-0001-9577-4989

R. P. Rhoads ( $\odot$ https://orcid.org/0000-0002-5205-5834

L. H. Baumgard ๑ https://orcid.org/0000-0002-3077-5996 